\title{
Practices and Theories of Contingency in Renaissance Approaches to Nature ${ }^{1}$
}

\author{
Pietro Daniel Omodeo \\ Ca' Foscari University of Venice \\ Department of Philosophy and Cultural Heritage \\ ERC EarlyModernCosmology (Horizon 2020, GA 725883)
}

\begin{abstract}
In the Middle Ages the concept of contingency was thought in connection with practice as a bridge between freedom and providence, indetermination and necessity. In theology and ethics, natural contingency was seen as the necessary presupposition for free will, human responsibility and salvation. In the Renaissance, the concept of contingency was transplanted from the ethical and theological fields to ontology and epistemology, in order to support the natural and methodological reflection on the practical arts. Owing to advances in technology and the arts, the articulation of theory and practical experience was a theoretical challenge for practitioners with theoretical predisposition as well as for learned scholars with practical bias in disciplines as varied as mechanics and medicine. In this context, as I will argue, contingency permitted to conceptualize the link between experience and theory. The theoretical reflection on practice was even extended to literary theory, especially poetical composition, on the basis of theoretical conceptions crossing heterogeneous realms of human experience, practice and knowledge. In fact, it was assumed that nature and human activity are a continuum and the creative power of human ingenuity and skillfulness is akin to forces operating in nature. In this essay, I will show that the Renaissance connection of practice and theory in the discourse on experience and its codification presupposed an ontology and an epistemology of contingency.
\end{abstract}

\section{Contingency and practice in Scholastic and post-Scholastic conceptions}

Contingency can be aptly understood as a twofold reference of an event or an action to its facticity as well as to the spectrum of other (but not actual) possibilities (Luhmann 2013, 40). ${ }^{2}$ In Scholastic logic, the modal category of contingency was commonly defined as "that which is neither impossible nor necessary" (quod est nec impossibile nec necessarium). Applied to ontology, it was redefined in existential terms as "that which is real but not so by necessity" (id, quod est sed potest non esse) (Vogt 2011, 51-59). In the Latin Christianized world,

\footnotetext{
Pietro Daniel Omodeo

Max Planck Institute for the History of Science Berlin

e-mail: pdomodeo@mpiwg-berlin.mpg.de

${ }^{1}$ This essay is a continuation and expansion of themes discussed in Omodeo and Renn (2013). I am particularly thankful to Jürgen Renn for his valuable suggestions and the thorough discussion of the themes of this essay.

${ }^{2}$ Luhmann calls this a "doppelte Referenz von Möglichkeit und Sein."
} 
contingency applied to reality as a whole, i.e., as the creation of the Almighty in accordance with his inscrutable will. As John Duns Scotus (1265-1308) put it, "there is contingency in the things due to God" (est contingentia in rebus, quia a Deo) (Scotus 1994, 140).

This conception would later become common good in philosophy, as is clearly witnessed by its centrality in Gottfried Wilhelm Leibniz's (1646-1716) logico-metaphysical speculations, many centuries after Scotus (Shepers 1965). However, contingency did not only refer to reality as a totality but also to events taking place within this totality. In this second sense, it was referred to the corruptibility of worldly phenomena, in particular of events occurring in the sublunary sphere. In the realm of 'coming-to-be and passing-away' - the peripatetic generatio et corruption - it was material imperfection and human sin that accounted for deviations from God's commands. These orders found expression either as natural laws or as moral requirements.

In Thomas Aquinas's (1225-1274) view, accomplished necessity or necessitas absoluta pertains only to immaterial beings and heavenly bodies. Drawing on the Aristotelian distinction between superlunary perfection and sublunary corruption, he maintained that the only physical beings that are caused by necessity are those, in which the form fulfills all potentialities of their matter. This suits to heavenly bodies. In the case of sublunary bodies, their forms are imperfectly realized since matter, as the potentiality to take different forms, is at the origin of their contingency. Matter is the source of the possibility to realize or not to realize inner tendencies prescribed by God (Summa contra Gentiles II 15, cf. Thomas 1982, 32). Additionally, since human will is able to produce effects that are not necessitated, human freedom (liberum arbitrium) is a further source of contingency.

It goes without saying that contingency, as expression of freedom and moral choice, was connected with concerns about salvation and redemption from a fallen state of sin. Arguably, the ethical and religious requirement to cope with worldly contingency and the imperative to master it was already crucial to Augustine's anthropology, although he did not use the expression 'contingentia' (Markschies 2016). Aquinas fully articulated this theme in his discussion about the moral tension required to overcome passions. He saw them as natural determinations, especially descending from starry influences (Summa theologiae, pt. 1 question 115, article 4):

\footnotetext{
Astrologers are able to foretell the truth in the majority of cases, especially in a general way. But not in particular cases; for nothing prevents man resisting his passions by his free will [per liberum arbitrium]. Wherefore the astrologers themselves are wont to say that "the wise man will master the stars", forasmuch as, to wit, he conquers his passions. ${ }^{3}$
}

The idea that astrology served to master nature and passions found its ultimate source of legitimation in the Ptolemaic views of the Centiloquium. A Renaissance estimator of Ptolemy's astrology such as Philipp Melanchthon (1497-1560) - himself a translator of the

\footnotetext{
3 "Et ideo astrologi ut in pluribus vera possunt praedicere, et maxime in communi. Non autem in speciali, quia nihil prohibet aliquem hominem per liberum arbitrium passionibus resistere. Unde et ipsi astrologi dicunt quod sapiens homo dominatur astris, inquantum scilicet dominatur suis passionibus." Quoted from http://dhspriory.org/thomas/summa/FP.html (Accessed 18 January 2016), translation slightly revised.
} 
Quadripartitum (Ptolemy 1553) ${ }^{4}$ - emphasized the Christian character of the conception of Creation as intrinsically contingent, as a whole, and permeated by contingency, in its parts. ${ }^{5}$ In his eyes, contingency informed a picture of the world that avoided two opposite evils, Stoic fatalism and the Epicurean view that the world is ruled by chance. In fact, contingency suits a vision of God as a wise king prescribing natural and ethical laws to His subjects without necessitating them (Melanchthon 1550, 31r-v). In the chapter "De contingentia" [On contingency] of his and his pupil Paul Eber's (1511-1569) Initia doctrinae physicae [Introduction to Physics] (1549), he argued that material vagaries and human freedom are the two sources of contingency in nature. They mediate between the perfection of divine laws and material imperfection.

In the Renaissance, the theme of contingency did not only inform ethics, theology, astrology and post-Aristotelian natural philosophies but also the emerging mathematical physics. Galileo Galilei's (1564-1642) discussions on dynamics with his mentor, Guidobaldo del Monte (1545-1607), bear witness to penetration of the theme of contingency in the natural conception underlying his research. In a letter to Del Monte (Padua, 29 November 1602) (Galileo 1968, vol. 10, n. 88, 97-100), he addresses the problem of the discrepancy between mathematical codification of general laws and phenomenal observation in the context of a defense of his own mathematical investigation of motion:

As for your question, I fully agree with your Excellency that abstract geometrical propositions are altered as soon as we cope with matter, owing to its contingency [per la sua contingenza]. As we cannot have a certain science of these perturbed [propositions] the mathematician is exempted from speculating on them. (Galileo 1968 , vol. 10,100$)^{6}$

This statement, delivered by one of the founding fathers of modern physics, does not imply any skepticism concerning the possibility of a mathematical inquiry of nature. Rather, it is in line with a long tradition regarding nature as the realm of contingency. Galileo denies the necessary occurrence of natural phenomena without renouncing mathematical physics altogether. One has just to bear in mind that material processes cannot accomplish mathematical perfection although they follow geometrical patterns or strive toward their realization. The challenge that Galileo and other innovators were facing was to offer a scientific theory capable of connecting mathematical universality, on the one hand, and experience, on the other (Renn-Damerow-Rieger 2001). This problem especially affected the status accorded to the practical arts - mechanics, astrology and medicine - in which concreteness and experience were the two pillars.

\footnotetext{
${ }^{4}$ Melanchthon accomplished the translation of Ptolemy's astrological work along with Joachim Camerarius.

${ }^{5}$ On Melanchthon's astrology and physics, see Kusukawa (1995).

6 "Perquanto al suo quesito, stimo benissimo quanto ne dice V.S. Ill. ${ }^{\text {ma }}$, e che quando cominciamo a concernere la materia, per la sua contingenza si cominciano ad alterare le proposizioni in astratto dal geometra considerate; delle quali così perturbate siccome non si può assegnare certa scienza, così dalla loro speculazione è assoluto il matematico."
} 


\section{The codification of experience as a problem in the epistemology of contingency}

In order to scrutinize the theme of contingency as a theoretical problem arising from the connection of theory and experience in the arts, it could be expedient to look at Renaissance scientist-engineers, for instance the military engineer Bonaiuto Lorini (1540-1611), on whom I will focus as a typical exponent of his time (cf. Lefèvre 1978, 96). He was the author of an extensive work on military fortifications, Delle fortificazioni [On Fortifications] (1596), outlining the theoretical and practical problems linked to construction and mechanics. In the dedicatory letter, to Philip of Spain, Lorini emphasized that, in order to become an accomplished architect, he had complemented mathematical formation (studii delle Matematiche) with practice:

I deemed it necessary to integrate learning with practice. For that purpose I decided to visit Flanders and other countries, in particularly to study their successes linked to the military art alongside the various opinions on fortification and the works, accomplished in accordance with them. However, I observed so much variety that one could easily believe that the art of fortification has no demonstrable foundation and that such important endeavors are made by chance. (Lorini 1596, A2r) ${ }^{7}$

In spite of initial doubts relative to the scientificity of architecture, Lorini claimed that he had become a proficient ingegner militare (militar engineer) by bringing together mathematical knowledge and mechanical practice.

The volume Delle fortificazioni aimed to provide a well-founded and overarching theory of architecture. The fifth book was devoted to the science and practice of mechanics, "in which the mechanical sciences and building practice are explained through very easy demonstrations according to the most certain rules" (dove con facilissime dimostrazioni si dichiarano le scienze delle mecaniche e la pratica di fabricare con le più certe regole). In it, Lorini warned the reader not to neglect practice. He stated that theory alone is not sufficient to realize the works described and explained in his work. As he explains, the application of abstract speculations fails if one does not take into account that the necessity of mathematical demonstrations does not fully apply to reality:

Before we continue, it is necessary to stress the difference between the pure and speculative mathematician and the practical mechanic [...]. The demonstrations and proportions that can be found among imaginary lines, surfaces and bodies, separated from matter, are not as perfect [as in abstract] when they are applied to material things. In other words, the mathematician's mental conceptions are not affected or altered by hindrances that are always and naturally connected with the matter with which the mechanic deals [...] although mathematical demonstrations are necessarily compelling. (Lorini 1596, 172) ${ }^{8}$

\footnotetext{
7 "Giudicai esser necessario di congiungere con gli studii, la pratica, per la quale volsi veder la Fiandra, et altri paesi, et particolarmente notare quei successi, che alla militia si appartengono: con le varie opinioni che sentivo proporre per fortificare, et dipoi l'opere che venivano fatte: onde viddi tanta diversità, che facilmente si saria potuto credere, che l'arte del fortificare non havesse alcun fondamento dimostrabile, et che una opera di tanta importanza venisse fatta a caso."

8 "Ma prima che più avanti procediamo, sarà necessario avvertire alla differenza che si ritrova tra il puro matematico speculativo et il mecanico pratico [...] perché le dimostrazioni, e proporzioni, che si ritrovano tra le linee superficie e corpi imaginari, e separati dalla materia, non rispondono così exquisitamente quando alle cose
} 
Lorini distinguished between the mathematician's concepts (concetti del matematico) and the mechanic's considerations and experience (considerazioni et esperienza del mecanico). Whereas the former person deals with necessary demonstrations, the latter has the capacity to cope with material reality. The opposition is that, typical of the Scholastic, between universal necessity and concrete materiality in the framework of an onto-epistemology of contingency. Lorini's reflection, however, is located outside academia, in that extra-academic sphere that has been aptly called in recent history of science "the artisanal experience of matter and nature" and an "articulation of artisanal experience and epistemology" (Smith 2004). To rest with knowledge of necessary theorems, as Lorini contends, would not help practice:

Hence descends that those who wish to deal with these works do not only need to know mathematics, in order to assess and realize them, but also have to be prudent and experienced mechanics. (Lorini 1596, 172) ${ }^{9}$

Lorini's science of architecture and mechanics is no knowledge of necessary truths but of the contingent, as it is the application of general laws to concrete circumstances. In this perspective, contingency looms large in the reflection on the connection between necessity and facticity. In this sense, contingency proves the crucial ontological and epistemological category to reflect on knowledge in connection with the practical arts.

The distinction between the theoretical and the empirical parts of architecture is reminiscent of epistemological considerations typical of the most reputed art of the time, medicine. In classical medicine, it was assumed that successful practice requires a skillful application of general knowledge to individual cases and a careful blending of empirical observation and philosophy (Temkin 1973, especially chap. 2). Accordingly, the epistemological problem underlying a field in which demonstrative knowledge and experience are simultaneously at stake was variously treated in Renaissance controversies over the epistemological status of medicine (Mammola 2012, especially chap. 3). The reputed physician Giovanni Argenterio (1513-1572) addressed the question whether medicine is a scientia or an ars, thus entering a heated debate especially discussed at the University of Padua. In his commentaries on Galen he came to the ambiguous conclusion that medicine has an in-between status. On the one hand, it is not as demonstratively compelling as Euclidean geometry but, on the other hand, it is not purely practical due to the speculative dignity of its natural principles, rooted in physics (Argenterio 1566, discussed in Mammola 2012, 185193).

Given this cultural background, it is not surprising that a polymath such as Girolamo Cardano (1501-1576) - bringing together the qualities of an excellent physician, mathematician, natural thinker and a practitioner in mechanics and astrology - offered one of

\footnotetext{
materiali si applicano, cioè che i concetti mentali del matematico non ricevono né sono sottoposti a quegli impedimenti che di sua natura sempre porta seco congiunti la materia, con che opera il mecanico [...] se bene la dimostrazione matematica ne persuade necessariamente [...]." The grammar and style of the original sources have been standardized and modernized, in particular punctuation and capitalizations.

9 “Adunque per le cose dette, ricorderò a quelli che si vorranno porre a così fatte imprese nel giudicare, overo comandare la essecutione, di qualsivoglia machina, essersi necessario non solo havere cognitione delle matematiche, ma ancora essere avveduto, e pratico mecanico."
} 
the most articulated methodological reflections on the relationship between speculative thought and practice. In his writings, he often stressed the limitations of pure theory disconnected from practice. As one reads in one of his medical aphorisms, the lack of exact quantification, established through practice, leads to failure in therapy:

In matters of practice [in negotiis], in contrast to matters of theory [in artibus generis] a vague acquaintance with the subject is not sufficient as it is necessary to know the quantities. One can do good by offering rhubarb to a patient sick with tertian fever even if one does not know the exact quantity, but it is better to keep silent or not to visit a patient if one has not become acquainted with the dose to be employed. (Cardano $1962,267)^{10}$

According to Cardano's practice-oriented concept of science, speculative and mathematical reasoning is empty if it is not connected with the senses and the experience gained by means of constant exercise and practice. Cardano even believed that the validity of an apparently pure science such as arithmetic is not just rational but also sensible. As one reads in his Artis arithmeticae tractatus de integris [Treatise in the Art of Arithmetic on Integers]: "This art [arithmetic] is indeed the most certain of all according not only to reason [ratione] but also to the senses. This is why it is the clearest among the mathematics" (Cardano 1663, vol. 10, 117a). ${ }^{11}$ Furthermore, in an essay on technical inventiveness, De inventione [On Invention], Cardano went so far as to defend the superiority of practice over theory, placing ingenuity (inventio) higher than knowledge, or wisdom (sapientia):

\begin{abstract}
Invention itself is higher than wisdom. In fact, human wisdom is rare owing to life's brevity and to the many impediments occurring to men even in their happiest times. By contrast, invention satisfies infinite cases at once. For example, he who demonstrates the reason why the angles of a triangle are equal to two rectangles, [demonstrated this] for infinite triangles, no matter how different they might be. The same applies to [demonstrations linked to] universals [species] [...]. Although the power of invention is infinite, it is only finitely actualized. Therefore this is the only thing almost capable of connecting finitude with infinity. It makes us resemble gods. (Cardano 1663, vol. 10, 90) ${ }^{12}$
\end{abstract}

As one reads, invention is the capacity to devise means for particular goals (inventio medii). The number of the means required depends on the discipline and the field. For instance, 'demonstration,' 'exercise' and 'instruments' are the three means that are necessary for music and medicine. In fact, an accomplished musician ought first to understands harmony (intelligit unde concordia), second, to be well exercised in his art and, third, to know how to play his instrument. All three means are indispensable conditions for musical perfection. Similarly, an

\footnotetext{
${ }^{10}$ Translation revised. Cf. Cardano $(1663,49 a)$ : "In negotiis non ut in artibus generis cognitio quidquam iuvat, sed quantitatem scire oportet: Possumus enim prodesse rhabarbarum exhibendo tertiana laboranti, etiamsi nesciamus quantitatem; at melius est tacere, aut non invisere clientem, si modum in actione adhibere nesciveris."

11 "Est vero hac ars [arithmetica] omnium certissima non tantum ratione, sed et sensu: unde et inter ipsas mathematicas ob hanc causam praeclarissima est."

12 "Inventio ipsa sapientia praestantior est: quoniam sapientia humana res est perexigua, tum ob vitae brevitatem, tum ob tot impedimenta, quae hominibus occurrunt etiam in temporibus felicissimis: at inventio infinitis simul satisfacit velut qui de triangulo demonstravit, quoniam tres angulos habet duobus rectis aequales, de infinitis et licet numero tantum differentibus: etiam iuxta species idem continget [...]. Itaque inventio potestate quidem infinita actu vero finita: Igitur haec pene sola infinitum cum finito coniungit. Nosque cum Diis continuat."
} 
accomplished physician is able to distinguish between health and disease, to detect illness and establish how to restore health.

The wide range of applications of human ingenuity is evinced by the variety of inventions Cardano listed in his autobiography, De vita propria [On His Own Life], in a chapter entitled "Notable discoveries of mine in various disciplines" (Quae in diversis disciplinis digna adinveni). They comprise inventions as different as the reorganization of logic and its application to mathematics, discoveries in arithmetic, especially in algebra, and alleged emendations in physics (e.g., the elimination of fire from the elements, the detection of the causes of many illnesses and their treatment, as well as experiments (experimenta) on rare diseases such as epilepsy, insanity and blindness. He moreover boasted that he had devised a method to transfer the observation of nature to the arts and the production of works (docui deducere contemplationem rerum naturalium ad artem et opus). Due to his many successes, he was proud of the title "the man of inventions" (vir inventionum) accorded to him by the man of letters, Andrea Alciato (1492-1550) (Cardano 1962, chap. 44, and 1663, vol. 1, 39b40a).

Cardano's proudness of his own ingenuity and practical skillfulness is not unique in the context of Renaissance Italy, in which greater social and cultural significance was allotted to "fabricated objects and the people who made them" and "the worlds of artisanal practice and the worlds of learning moved closed together" (Long 2011, 30). Cardano's attitude can be understood against the backdrop of a social environment in which technical and economical advance favored a new class of scientist-engineers, gratified by the recognition for their technical and theoretical expertise (cf. Lefèvre 2001 and Valleriani 2010). In the letter to the reader of the Italian edition of Del Monte's Le mechaniche [Mechanics] (1581), Filippo Pigafetta (1533-1604) reversed the bad name traditionally attached to practice, ascribing his positive assessment to a classical authority:

According to Plutarch, 'mechanic' is a very honored term as it is referred to the military profession. It suits the illustrious man who is capable to realize, with his hands and ingenuity, marvelous works, which are extremely useful and agreeable in life. (Del Monte 1581, Bl. b3r) $)^{13}$

The increased status of Renaissance technicians and practitioner was mirrored in the enhanced status allotted to their disciplines in the system of knowledge of the time. Cardano, for one, developed an epistemology ad hoc, namely a sensual epistemology according to which knowledge is a process of abstraction from the empirical to the universal:

\footnotetext{
13 "Mechanico è vocabolo honoratissimo, dimostrante, secondo Plutarco, mestiero alla Militia pertinente, et convenevole ad huomo di alto affare, et che sappia con le sue mani et co'l senno mandare ad esecutione opre maravigliose a singulare utilità et diletto del vivere humano." The same positive judgment can be found in Lorini (1596, 172): "Né sia alcuno, benché Signor grande, che si sdegni se con nome di mecanico venisse nominato, perché, come da Plutarco e da altri grandi autori è stato detto, esso nome è honorato appartenendosi solo a huomini di grande ingegno e valore, e che sappino co'l senno e con la mano ritrovare e mettere a essecuzione opere grandi, e massime alla milizia appartenenti." On the opposite 'prejudice' concerning 'vile mechanics,' see among others, Rossi (2001, 15-17).
} 
[Knowledge] is [...] an understanding threefold in nature. First, there is knowledge gained by my senses through the observing of innumerable things [...]. Secondly, there is an understanding of higher things obtained through the examination of their beginnings and pursued by conforming to certain principles. This aspect of knowledge is called proof because it is derived from wider application of the subject under consideration, or to place it in a clearer light or to give a general application from the particular. [...] The third stage of my knowledge is that of things intangible and immaterial, and by this I have come wholly as a result of the ministrations of my [...] spirit. [...] The use of amplification and lucidity of understanding I have acquired partly from practice and partly at the inspiration of my spirit, for I devoted myself persistently to perfecting that intellectual flash of insight for more than forty years before I mastered it. (Cardano 1962, $245-247)^{14}$

Cardano's approach to the sciences was a theory of knowledge in which the senses, observation and experience are the beginnings of an inductive and generalizing process. This pre-Baconian attitude was not referred to a science of the necessary but rather to one that is epistemologically located at the intersection of universal necessity and material particularity. Ascribing a scientific status to disciplines connected with practice and experience implied to develop an epistemology of contingency that often corresponded to an ontology of contingency. This is the next theme I discuss.

\section{Nature: the living art and the realm of contingency}

Before we deal with contingency in Renaissance natural philosophies, it is expedient to stress the centrality of the epistemological reflection on art in the understanding of nature of the time. On the one hand, geometry was often deemed to offer an insight into the archetypal design of the universe in God's mind, according scholars such as Johannes Kepler (15711630). On the other hand, artisanal work helped Renaissance thinkers to conceptualize the act of creation by the Almighty and its continuation through nature. Resting on Plato's Timaeus and Pythagorean influences, Cardano argued that the number of the planets and the proportions of their distances could be detected by inscribing and circumscribing geometrical solids in spherical orbs. This conception, presented in his Encomium geometriae [Eulogy of Geometry] (1553), paved the way to Kepler's most famous geometrical reconstruction of the geometrical archetypes of the world in the Mysterium cosmographicum [Cosmographic Secret] (1596). As Cardano wrote,

It is well known that God, the greatest of all artisans [maximum Opificem], preserved geometrical proportion in the structure of the world. Nothing should be considered more attentively in that construction of his, or better still only that [proportion should be considered]. Perhaps somebody would ask whether the proportion of the seven planets can be grasped once that [cosmological] proportion is unveiled. Yes, indeed! (Cardano 1663, vol. $4,442 a)^{15}$

\footnotetext{
14 Translation slightly revised.

15 " [...] constat summam Geometriae rationem maximum Opificem in mundi constitutione conservasse: nihilque magis illa in eius constructione, imo et solam illam spectari debere. Sed forsitan quis quaerat, num ex hac ratione aperta septem erraticarum ratio habeatur? Certe sic."
} 
As for the correspondence between artisanal production and the causation of natural phenomena, the medieval adagio "ars imitatur naturam" (art imitates nature) was still widely accepted during the Renaissance. Lorini repeated this topos. In his volume on architecture, he located it in the framework of the humanistic conviction that a structural correspondence exists between the macrocosm and the microcosm, that is, between the world as a whole and man:

Many times I reflected on the marvelous order of Nature and I observed that it produces nothing imperfect. Rather, everything is perfect in his own species and genre and is directed towards the comfort and utility of mankind. As man is made in the image and likeness of God and is so-to-say the brother of Nature and the father of Art, I have come to the conclusion that he is forced to imitate Nature and to realize all of his good works through art in order, first, to honor God our Lord and, secondly, for the benefit of his neighbor. Thus, by mastering all other earthly creatures, he has to exceed their perfection inasmuch as his nobility is higher and philosophers called him, as a reasoning creature, 'microcosm'. (Lorini 1596, A3r) ${ }^{16}$

According to this Renaissance theme, the artisan's activity is the continuation of and improvement upon nature. Agostino Ramelli (1531-1600), in Le diverse e artificiose machine [Various Artificial Machines] (1588) furthered this theme by equating human production and natural action. He presented mechanics as a science aimed at producing marvelous effects independently whether its source is human or natural (Ramelli 1588, $7 v$ ). ${ }^{17}$

The separation between natural and artificial got blurred. It was often assumed that the practitioner ought not to make violence on nature in order to obtain the effects he wishes. Rather, the practitioner has to awake and canalize inner natural tendencies. The reputed mathematician Niccolò Tartaglia (1499-1557) pointed out that the action of the practitioner does not produce natural motion but rather gives nature the occasion to unfold its potentialities. He made this point clear in La nova scientia [The New Science] (1558), aimed to elevate ballistics to the rank of a scientia (Valleriani 2013). "It is evident - he wrote (Tartaglia 1558, $4 r$ ) - that the natural motion causes the violent and not the opposite. The violent never causes the natural, which indeed is caused by itself." ${ }^{18}$ In this respect, scholars in mechanics followed the same line of thought of practitioners in the 'wretched' fields alchemy and magic. For instance, Cornelius Agrippa of Nettesheim defined magic, in $D e$ incertitudine et vanitate scientiarum [On the Uncertainty and the Vanity of Sciences] (1527), as an art in the service of nature. It gives nature an 'opportunity' to produce its marvelous effects (Agrippa 1584, chap. 42). The same idea was picked up by Giambattista della Porta

\footnotetext{
16 “Avendo più volte fra me stesso considerato l'ordine maraviglioso della Natura, e chiaramente veduto non esser creata cosa alcuna imperfetta, anzi tutte (con forma al genere suo) perfettissime, et affine di apportar commodo et utile all'huomo, il quale essendo fattura et immagine di Dio, e per così dire, fratello della Natura, e padre dell'Arte, mi son mosso a credere che egli sia del tutto obligato ad imitare essa Natura, e con l'arte far tutte l'opere sue buone, e prima ad honore di Dio nostro Signore, e poi a beneficio del prossimo. Perciocché dominando tutte l'altre cose terrene, le deve superare di perfettione tanto più quanto si trova esser maggiore la sua nobiltà, come creatura ragionevole, e da' Filosofi paragonato ad un picciol mondo."

17 “[...] Sì come potrà vedere ciascuno che piglierà piacere di leggere il presente Volume, che io gli appresento, in cui scorgere si puote tutte quelle stupende cose, che la natura, 1'arte o lo ingegno humano con tal scienza possa, o sappia fare innanzi a gli occhi de i viventi."

18 "Per il che egl'è cosa manifesta che dal moto naturale si causa il violente, et non e converso, cioè che dal violente giamai viene causato il naturale, anci si causa per se."
} 
(1535-1615) in his twenty books on natural magic (completed in 1589 as an extended reworking of an earlier work, published in 1558). In the section "Quid sit Magia" [What is magic] of this Magia naturalis [Natural Magic], he warned his readers as follows:

Hence you, who will be introduced to magic, should know that magical works are nothing but the works of Nature, since the art serves it with great diligence. When it is noted that something is missing from the natural harmony [naturalis cogniatio], this is restored through vapors and elements at the right time, for instance in agriculture Nature generates the herbs and the harvest that the art has prepared. (Della Porta 1650, $3-4)^{19}$

Della Porta added that the ancient Egyptians went so far as to identify magic and nature, arguing that the forces that act in the world are the same that magicians canalize and use for their purposes (Della Porta 1650,3).

To mention a similar perspective in alchemy, Benedetto Varchi (1503-1565) in his Questione sull'alchimia [Alchemical Inquiry] (1544), claimed that the transmutation of metals is the fruit of a collaboration between the artisan and nature:

It is not the art or the alchemist that generates and produces gold. It is nature. But the latter has to be prepared and helped by the alchemist and [his] art. It is the same as with health which is not restored in a sick body by medicine or the physician but by nature, if it is prepared and helped by the physician and [his] medicine. [...] It is hence evident that the art does not make the metals. It is nature. And art is instrumental. (Varchi 1827, $21-22)^{20}$

Alongside this naturalization of art, nature was ascribed an artisan-like subjectivity. As Cardano remarked in De subtilitate [On Subtlety] (1550) (Cardano 1663, vol. 2, 360a): "The motion [of the machine] does not originate in a soul [as an external agent]. Rather, it originates in nature itself [...]. In fact, that which moves an element is internal." ${ }^{, 1}$ Therefore, nature is not forced to act by an external agent, e.g., the soul of the mechanist. Rather, it is a subject waiting for the right conditions to unfold its potentialities.

It should be added that, in this perspective, practitioners' experience could be seen as an access to the interiority of natural processes. In other words, while art was seen as the improvement upon and continuation of nature ex parte objecti, the action of nature could be understood through artisanal experience, ex parte subjecti. This line of thought informed, among others, the philosophy of mathematics of a philosopher such as Giordano Bruno (1548-1600). In his collection of anti-Aristotelian theses, Comoeracensis Acrotismus [Chambray Acrotism] (1588), he described Nature (with capital 'N') as a living art producing all forms and beings out of herself, moved by an internal drive akin to that of the mathematician giving shape to geometrical figures in his mind:

\footnotetext{
19 "Unde vos, qui Magiam visuri acceditis, nil aliud Magiae opera credatis, quam Naturae opera, uti ars ministra, et sedula famulatur. Sic ubi enim aliquid naturali cognationi deesse noscit, per vapores et numeros opportunis illud instaurat temporibus, ut in Agicultura ipsa Natura herbas, et segetes parit, ars vero praeparat."

20 'Non l'arte, o l' Archimista genera, e produce l'oro, ma la natura disposta però, et aiutata dall'Archimista, e dall'arte, non altramente che la sanità in un corpo malato non si rende né dalla medicina, né dal medico, ma dalla natura disposta però, e aiutata del medico, e dalla medicina. [...] Onde si vede manifestamente, che non l'arte fa i metalli, ma essa natura, se non quanto l'arte è strumento."

21 "Motus non ab anima sed a natura est [...]. Intimum igitur est, quo movetur elementum."
} 
NATURE [...] is a living art and an intellectual power of the soul that is not alien but proper, not external but inner, not chosen but essential, and that continuously shapes matter. It does not operate from the outside like a sculptor using his discursive faculty and instruments. Rather, it operates just as the geometer moves and shapes his own spirit from the inside when he vividly imagines [geometrical] figures. (Bruno 1962, 80) ${ }^{22}$

The close link between such a dynamic vision of nature and contingency is clearly expounded by Nicholas Cusanus (1401-1464), who was one of Bruno's sources (Secchi 2006) and has been praised in intellectual history as one of the most important Renaissance thinkers as far as cosmology is concerned (Cassirer 1927 and Koyré 1957). In De docta ignorantia [On Learned Ignorance] (1440), Cusanus advanced an ontology based on the modal categories of necessity, possibility and contingency. He ascribed each of them to one of the three components of the universe: form, matter and spirit. Taking into account also the divine, the universal modes of being are four: God's absolute necessity, formal necessity (which he calls necessitas complexionis), material possibility (possibilitas) and the nexus or 'connection' of necessity and possibility generating universal contingency. The latter three modes are inseparably intertwined in nature.

By calling the third component of the triad 'spirit,' Cusanus stressed the dynamic character of nature. In fact, he defined it as a motion connecting form and matter. It is present everywhere, in the starry heavens, in the planets and in the earthly sphere. Therefore, everything in this world is the product of a spiritual motion connecting form and matter. Out of this motion universal contingency is produced as the mediation between formal constraint and material indetermination:

Form descends, so that it exists contractedly in possibility; that is, while possibility ascends toward actual existence, form descends, so that it limits, and perfects, and terminates possibility. And so, from the ascent and the descent motion arises and conjoins the two. This motion is the medium-of-union of possibility and actuality. (Cusanus 1988, 88) (23 $^{2}$

Cusanus also calls this spiritual connection 'nature':

Therefore, this spirit, which is called nature, is spread throughout, and contracted by, the entire universe and each of its parts. Hence, nature is the enfolding (so to speak) of all things, which occur through motion. (Cusanus 1988, 88) $)^{24}$

Cusanus's perspective is significant for our present inquiry insofar as it constituted an example of a philosophy of natural contingency. It extended the immediate experience of the

\footnotetext{
22 "DE NATURA: [...] Ipsa est ars viva et quaedam intellectualis animae potestas, non alienam sed propriam, non extrinsecus sed intrinsecus, non electione tali, sed essentia tali, materia perpetuo figurans: utpote non sicut statuaris externe, cum discursu, et instrumento operatur, sed perinde ut Geometra, dum vehementer quodam affectu figuras imaginatur, spiritum eius intimum imaginatione movet atque figurat."

${ }^{23}$ Cf. Cusanus (1932, 97): "Forma [...] descendit, ut sit contracte in possibilitate; hoc est, ascendente possibilitate versus actu esse descendit forma ut esse finiens, perficiens et terminans possibilitatem. Et ita ex ascensu et descensu motus exoritur conectens utrumque. Qui motus est medium conexionis potentiae et actus."

${ }^{24}$ Cf. Cusanus (1932, 97-98): "Est igitur hic spiritus per totum universum et singulas eius partes diffusus et contractus, qui natura dicitur. Unde natura est quasi complicatio omnium, quae per motum fiunt."
} 
sublunary world to the entire universe. Arguably, it paved the way to the modern principle of cosmological homogeneity, fundamental for Brunian, Cartesian and later speculations about the unity of the laws of nature. According to Cusanus's speculative conceptualization of the experience of contingency and more or less explicit treatments by later scholars dealing with the onto-epistemology of practice and the arts, human beings and nature operate as creative subjects contingently producing works and events that are accorded to formal necessity only up to a certain degree.

\section{Divine and human creativity: an access to worldly contingency}

I have so far explored the Renaissance conceptualizations of practice and the arts sub modo contingentiae. An onto-epistemology of contingency, as I said, underpinned the codification of practical knowledge. I have moreover pointed to Cusanus and Buno's generalization of the experience of contingency to the level of a worldview. Most importantly, artisanal experience was recognized as a clue revealing of the action of nature. Along this line, the problem of $\pi$ oínбıs, creativity and production, received cosmological import. The question of how to conceive the creative process concerned scientists, engineers and natural philosophers as much as literary critics. During the Renaissance, in fact, the question of $\pi$ oínбı $\varsigma$ was intensely debated among literary critics and theorists concerned with the foundations of the art of poetry, or poetica (Hathaway 1962, Weinberg 1961). Some scholars even claimed for poetics the high status of a 'science' just like scholars in the arts of medicine, mechanics, architecture, ballistics and the science of materials struggled to confer to their fields of study the same epistemological dignity.

Hence, the concurring efforts to construct a science of poetry and to formalize the experience embedded in craftsmen's skills were at the same time epistemic and epistemological. The codification of art as a science (with its principles, its laws, the definition of the technical terms and the systematic interconnection of its elements) was accompanied by legitimating strategies at the meta-level of theory of knowledge. The philosophical justification of the validity of the epistemic status of practical knowledge was a challenging intellectual endeavor. It encompassed discussions on method and on the philosophical foundations of knowledge. Especially in the context of the defense of the scientific dignity of the arts, the problem of the genesis of knowledge came to the forefront. In other words, the processes of production and acquisition of knowledge through experience became the central epistemological issue at the expenses of epistemologies of the adequatio in the natural sciences and the aesthetics of imitatio in literature and the plastic arts. In his Italian commentary to Aristotle's Poetics, Lodovico Castelvetro (1505-1571) criticized Aristotle himself when he claimed that the essence of poetry is inventiveness and not imitation: 
A thief of others' inventions deserves to be despised and punished. The poet that steals [from other poets should be treated] in this manner. In fact, his essence rests on invention, and without invention he cannot be a poet. (Castelvetro 1978, 289) ${ }^{25}$

In another standard commentary of the Poetics, Poetices libri septem [Seven Books on Poetics] (1561), Julius Cesar Scaliger (1484-1558) did not renounce imitation as the cornerstone of poetry. However, he closely connected it with creativity, as he stated that poetry imitates nature's productivity instead of its products. Poetry, he wrote, can be seen as a second nature and the poet as a second God:

Only poetry encompasses all [literary genres]. It is the most excellent since the others [...] represent things as they are, like a portrait for the ears. By contrast, the poet brings into existence not only a second nature and various destinies but at once makes himself like a second god. In fact, the other sciences are similar to portrayals of that which the Creator has already brought into existence. By contrast, poetry most splendidly produces the species of that which exists or does not exist. Therefore, it does not seem that it presents things as they are like somebody who repeats, as is the case with other disciplines. Rather, it creates them like a god. For this reason, [poets] share their name with [God] not just by a human convention but rather from natural providence. The wise Greeks suitably created the name [of poetry] from the verb $\pi$ oteĩ [to create]. (Scaliger 1994, 70-72) ${ }^{26}$

Discussions on the capacity of concepts or of artistic forms to mirror a given reality had to be accompanied by considerations on scientific and artistic expressivity. Scaliger remarked that a poem couldn't be understood independently from the creative act, or poesis, that bought it into existence and from its creator, the poet. Similarly, there is no discovery independent from research and researchers:

Poem is the work itself, that is to say, the forged matter. Poesis is the rationale and the form of the poem. Therefore there are as many nominalized verbs as names: poema corresponding to $\pi \varepsilon \pi$ oín $\mu \alpha 1$, poesis to

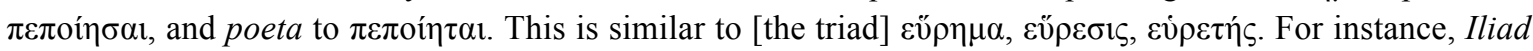
is a poem, Homer a poet and the rationale and form out of which Margites is created, poetry [poesis]. Poetics is a science, that is, the capacity to apply the learned precepts to the composition of that, which we call poetry [poesin]. (Scaliger 1994, 88 and 90$)^{27}$

\footnotetext{
25 "Ma se uno involatore delle 'nvenzioni altrui dee essere schernito e punito, sì dovrebbe essere il poeta involatore, la cui essenzia consiste nella 'nventione e senza essa inventione non è poeta." On Renaissance commentaries to Aristotle's Poetics, see Kappl (2006) and Schmitt (2002).

26 "Sola poesis haec omnia complexa est, tanto quam artes illae excellentius, quod caeterae, ut dicebamus, res ipsas uti sunt repraesentant, veluti aurium pictura quadam. At poeta et naturam alteram et fortunas plures etiam ac demum sese istoc ipso perinde ac deum alterum efficit. Nam quae omnium opifex condidit, eorum reliquae scientiae tamquam actores sunt. Poetica vero, cum et speciosius quae sunt et quae non sunt eorum speciem ponit, videtur sane res ipsas non ut aliae quasi histrio narrare, sed velut alter deus condere, unde cum eo commune nomen ipsi non a consensu hominum, sed a naturae providentia inditum videatur. Quod nomen Graeci sapientes

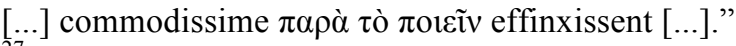

27 "Poema est opus ipsum, materia, inquam, quae fit. Poesis autem ratio ac forma poematis, ut habeas a tribus verbi personis totidem nomina: poema - $\pi \varepsilon \pi$ oí $\mu \alpha 1$, poesis $-\pi \varepsilon \pi$ oín $\sigma \alpha 1$, poeta $-\pi \varepsilon \pi$ oí $\tau \alpha \alpha$, quemadmodum

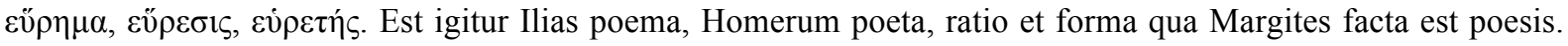
Poetice vero scientia, id est habitus ex dispositione praeceptionum quibus docemur ad conformationem hanc quam poesin appellamus."
} 
Scaliger thus emphasized the continuity between literary theory and epistemology. His views emerged from discussions on creativity and the creative power of the artist and the scientist, nature and, eventually, God the Creator.

It should be added that expressiveness is the cornerstone of the literary theory of the most reputed neo-Platonic philosopher of the late sixteenth century, Francesco Patrizi (1529-1597), also known for the natural philosophy and cosmology he developed in Nova de universi philosophia [New Philosophy of the Universe] (1591) (See Rossi 1977, and Seidengart 2006, 116-24). Disputing against the dogma of imitation, he maintained that the essence of poetry is enthusiasm or divine inspiration, which he called a furore poetico (poetic frenzy). In a letter to a correspondent, written in 1552, he discussed the different forms of furore based on Plato's Phaedrus. First, he assumed that there is a 'natural' furore that elevates humankind above the animal reign. Second, there is a 'divine' furore descending from the heavens, which can be divided into poetic, mystical, prophetic and loving furores. An accomplished poet needs the poetic furore in addition to an elevated ingenuity. Furore descends from the Muses, that is, from planetary influences. It is a continuation of divine action in the world which pours from the cosmos into the poet's soul. Depending on the different constellations and planets (here equated with the Muses) presiding over the nativity, an author will have a bias towards various forms of poetical inspiration - e.g., epic, tragic or amorous.

\begin{abstract}
Democritus and Horace thus attribute such ingenuity and such frenzy [...] to the excellent poet who is worthy of his name. In the following, we will understand in which manner the two characteristics are present in the poet if we first grasp that a rational and eternal soul rules the entire corporeal universe. Similarly, souls move and excite the low elements. The heaven of the Moon is animated in the same manner. Those of Mercury, Venus, the Sun, Mars, Jupiter, Saturn and, last but not least, the starry [heavens] have their own rational souls, distinguished from each other. The wise men of our world call the eight souls of the eight celestial spheres 'Muses.' They derive this name from the name of 'music' and from the very gentle music produced by the heavens moved by the aforementioned souls and by the universal [soul] that rules and tempers all the others. (Patrizi 1971, vol. 3, 449-450) 28 $^{28}$
\end{abstract}

In Patrizi's neo-Platonic philosophy, the human soul is seen as a continuation of the worldly soul as well as of the planets' souls. From this viewpoint, poetic creation is akin to a divine act of creation. Hence, poetry is a means to illuminate the very essence of nature and reality. Behind natural phenomena, transformations and celestial geometries, a creative force acts akin to the poets' $\mu \varepsilon \dot{\lambda} \mathrm{o} \varsigma$, that is, to their skilful use of words, harmony and rhythm.

Hence, in this very general meaning, 'poet' refers to all craftsmen [artefice] and all makers of something unprecedented. In this sense, [Plato] called the maker of the world a 'poet', and his great follower Plotin called Providence the 'worldly poet.' In fact, the former made the world and the latter continues to make

\footnotetext{
28 "Tale ingegno, adunque, e tal furore [...], ricerca Democrito e Horatio in un poeta che voglia esser eccellente e degno di cotanto nome. Ma in che maniera nel poeta e l'uno e l'altro si venga a fare noi nel nostro corso il vedremo, se avertiremo prima che tutto questo universo corporeo è animato e retto da un'anima ragionevole e eterna, et che parimente i bassi elementi sono mossi e agitati da simili anime; et che questo ciel della Luna sia del medesimo modo animato, e ancor quello di Mercurio, e quel di Venere, del Sole, di Marte, di Giove, di Saturno, e finalmente lo Stellato habbiano ciascuno l'anima sua ragionevole, appartata da quella de gli altri. Le quale otto anime delle otto sfere celesti, e quella dell'universo chiamarono gli huomini savi del nostro mondo Muse, prendendo cotal nome dalla musica e dall'armonia soavissima che causano i cieli, mossi dalle predette anime e dall'universale, la quale tutte l'altre governa e tempera [...]."
} 
unprecedented things in the world. Hence, 'poetry' means creation [the making of such things], 'poem' means its product, and 'poetic' the art of creation. (Patrizi 1969, Vol. 2, 272) ${ }^{29}$

Patrizi's case shows the proximity between literary theory and cosmology turning about the

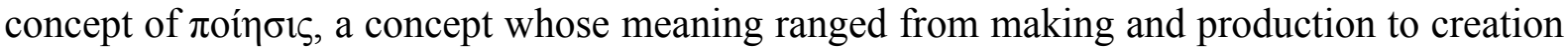
and poetical composition. In various ways, scholars such as Cardano, Bruno, Kepler and Galileo considered natural order and geometries as the mobile expression of inner forces just as most prominent literary critics such as Patrizi and Scaliger treated the poet's creativity as the unfolding of inner tendencies akin to those of nature. In other words, poetical creation was explained by analogy with natural and divine creation and vice versa natural and divine creation was made accessible through the human experience of creativity.

Furthermore, the Renaissance reflection on literature emphasized expressiveness just like the art of mechanics emphasized the processes of production rather than than static artificial objects (Omodeo and Renn 2016, 135-137). Art was thus reflected in its dynamics while nature was regarded as the artistic drive forging and forming the world from the inside according to mathematical proportions. In Kepler's astronomy, the geometries of planetary orbits are the mobile product of inner forces. According to him, 'orbit' refers to the path together with its physical causes, expressed as physical laws (Goldstein and Hon 2005, 76). In this 'physicalization of mathematics' ${ }^{30}$ the shape and the speed of astronomical motions depend on the force emanating from the Sun, that is, on the physical cause of geometrical effects (Wilson 1968).

The inquiry of the inner causes of mathematical phenomena in nature was at the basis of Galileo's on dynamics and cosmology. In his experiments on projectile trajectories he carried out exact measurements in order to demonstrate that such trajectories produce parables with the same shape as a hanging chain (Renn-Damerow-Rieger 2001). The discrepancy of the measurement with such a theoretical assumption did not induce Galileo to abandon his theory. Rather, he accounted for the discrepancy referring to what I would call an onto-epistemology of contingency. According to this view, the natural production of mathematical structures is affected by processes in which materiality introduces a deviation from geometrical perfection (Omodeo and Renn 2016, 139-144).

The same leitmotiv can be found in Galileo's cosmogony. In his early work De motu [Om Motion] Galileo pointed out cosmological contingency and referred to it as a sign of Divine Providence and pitted it to chance:

Now, so far as I have read, no other reason for the existing arrangement is adduced by the philosophers than that everything must be dispose in some arrangement, and that it has pleased Providence on high to employ this arrangement. [...] Yet, if we look at the matter more carefully, surely we shall not have to conclude that nature was under no necessity in this arrangement, and obtained no advantage from it, and that she some how

\footnotetext{
29 "Adunque, per questo così generale significato, poeta sarà ogni artefice e ogni facitor di cosa che non più sia stata, secondo che nel Timeo [Platone] chiamò poeta il facitor del mondo, e Plotino, il grande, suo seguace, poeta mondano chiamò la providenza, perché quelli fece il mondo, e questa tuttavia nel mondo fa cose non state prima. E poesia sarà facitura di cosa tale e poema ogni opera così fatta, e poetica l'arte di farla."

${ }^{30}$ Ofer Gal and Raz Chen-Morris give important clues about the epistemology underlying the physicalization of mathematics in Early Modernity (Gal and Chen-Morris 2013, chap. 4). On the move towards a physicalization of mathematics also see Schuster $(2013,56)$.
} 
operated solely according to whim and chance. Since I believed that it was impossible to entertain such a view about provident nature, I anxiously sought from time to time to think of some cause, if not necessary, at least reasonable and useful. And, in truth I have found that nature chose the existing arrangement, with complete justice and with consummate wisdom. (Galileo 1960, 14-15) ) $^{31}$

He assumed that the speed of the planets around the Sun was reached after a free fall produced by the divine arifex and that free fall is accelerated whereas circular motion's velocity is uniform. Resting on those premises, in the Dialogo sopra $i$ due massimi sistemi del mondo [Dialogue Concerning the Two Chief World Systems] (1632), Galileo tried to calculate the height from which God threw the celestial bodies at the moment of the creation of the Copernican system. For his computations, he used Kepler's planetary periods, derived from the Mysterium cosmographicum, and applied his own law of fall (Büttner 2001). In spite of the lack of perfect agreement between observation and computation, Galileo was satisfied with the result to the extent that he celebrated his Platonic experiment in the Discorsi $e$ dimostrazioni matematiche intorno a due nuove scienze [Discourses and Mathematical Demonstrations Relating to Two New Sciences] (1638):

Sagredo: [...] This conception is truly worthy of Plato; and it is to be all the more highly prized since its underlying principles remained hidden until discovered by our Author who removed from them the mask and poetical dress and set forth the idea in correct historical perspective. In view of the fact that astronomical science furnishes us such complete information concerning the size of the planetary orbits, the distances of these bodies from their centers of revolution, and their velocities, I cannot help thinking that our Author (to whom this idea of Plato was not unknown) had some curiosity to discover whether or not a definite "sublimity" might be assigned to each planet, such that, if it were to start from rest at this particular height and to fall with naturally accelerated motion along a straight line, and were later to change the speed thus acquired into uniform motion, the size of its orbit and its period of revolution would be those actually observed.

Salviati: I think I remember his having told me that he once made the computation and found a satisfactory correspondence with observation. But he did not wish to speak of it, lest in view of the odium which his many new discoveries had already brought upon him, this might be adding fuel to the fire. But if any one desires such information he can obtain it for himself from the theory set forth in the present treatment. $(\text { Galilei 1914, 261-262) })^{32}$

\footnotetext{
31 "Huius distributionis non alia, quod legerim, a philosophis affertur causa, nisi quod in aliquem ordinem erant cuncta disponenda, placuit autem Summae Providentiae in hunc distribuere. [...] Attamen, si rem accuratius spectemus, non erit profecto existimandum, nullam in tali distributione necessitatem aut utilitatem habuisse naturam, sed solum ad libitum et casu quodammodo operatam esse. Hoc cum provida natura nullo pacto existimari posse perpenderem, interdum anxius fui in excogitanda, nisi necessaria saltem congruente ac utili, aliqua causa: ac profecto, non nisi optimo iure summaque prudentia hunc elegisse ordinem naturam, comperi.“

32 "Sagr. [...] Il concetto è veramente degno di Platone; ed è tanto più da stimarsi, quanto i fondamenti taciuti da quello e scoperti dal nostro Autore, con levargli la maschera o sembianza poetica, lo scuoprono in aspetto di verace istoria. E mi pare assai credibile, che avendo noi per le dottrine astronomiche assai competente notizia delle grandezze de gli orbi de i pianeti e delle distanze loro dal centro intorno al quale si raggirano, come ancora delle loro velocità, possa il nostro Autore (al quale il concetto Platonico non era ascosto) aver tal volta per sua curiosità auto pensiero d'andare investigando se si potesse assegnare una determinata sublimità, dalla quale partendosi, come da stato di quiete, i corpi de i pianeti, e mossisi per certi spazii di moto retto e naturalmente accelerato, convertendo poi la velocità acquistata in moti equabili, si trovassero corrispondere alle grandezze de gli orbi loro e a i tempi delle loro revoluzioni.

Salv. Mi par sovvenire che egli già mi dicesse, aver una volta fatto il computo, ed anco trovatolo assai acconciamente rispondere alle osservazioni, ma non averne voluto parlare, giudicando che le troppe novità da lui
} 
Although Galileo boasted he had discovered the truth underlying Plato's myth, the passage from scientia poetica to a mechanic account of the formation of the solar system keeps the central idea that the phenomena should be explained through their inner causes and that the latter realize their effects in a contingent manner - in both senses of contingency, that is, as referred to the whole and to the parts.

\section{Concluding remarks}

In recent years the attention of scholars in early-modern science has been increasingly led by the question about role in the 'Scientific Revolution' of such figures as 'scientist-engineers' (Lefèvre 2001 and Valleriani 2010) and 'artisan-practicioners' (Long 2011), of the 'artisanal experience of matter and nature' (Smith 2004) and the various dimensions of 'practical knowledge (Valleriani 2017). In this essay, I have brought into focus the epistemological and ontological conceptions underlying Renaissance conceptualizations of practical knowledge. The attention to practical experience and the juncture of theory and practice in different arts architecture, mechanics, medicine and even poetry - led to a dynamic view of nature and knowledge. We could call this early-modern perspective on practice and knowledge a 'praxeology', as the cornerstone of such a philosophy of science was contingency seen as the central category for both an ontology and epistemology taking into account practical experience and generalizing it to the level of a world picture. Medieval authors such as Aquinas and Scotus dealt with natural contingency as the corollary of Christian theology and ethics, namely an ethics of responsibility and moral improvement. During the Renaissance, the social and epistemological rise of the practical arts led to an enlargement of the medieval discourse on contingency from the theological and ethical realms to the technical, artisanal and artistic spheres. In many cases, the articulation of practical knowledge and epistemology was germinal and not fully developed, as was the case in writings by authors in architecture and mechanics such as Lorini, Tartaglia and Del Monte. A liminal scholar such as Cardano, working at the intersection of philosophical literacy and medical and technical practice, developed an articulated reflection on practical knowledge, putting at its center inventiveness and creativity. Similar concerns about the epistemological status of creativity were crucial in Renaissance theories of poetry, for instance in the works of Scaliger and Patrizi, whose reflection on poetical composition and inspiration deepened the comprehension of ingenuity and skillfulness as had been developed in connection with other arts. All of these theoretical efforts converged into a praxeology, or an onto-epistemology of contingency, according to which the inner tendencies of nature, its productive forces and processes are akin to those revealed through the experience of the arts. Finally, dynamic conceptions of the world such as the natural philosophies and cosmologies of Cusanus and Bruno, brought to a universal level

scoperte, che lo sdegno di molti gli hanno provocato, non accendessero nuove scintille. Ma se alcuno avrà simil desiderio, potrà per sé stesso, con la dottrina del presente trattato, sodisfare al suo gusto." 
the intuition of contingency. Contingency can be seen as the ontological and epistemological category connecting Renaissance philosophy and practices, science, technology and the arts, in an age in which classical divides between speculative and practical work and between episteme, technology and artistic experience were casted into doubt and blurred.

\section{Acknowledgement}

This essay is an outcome of a project that has received funding from the European Union's Horizon 2020 Research and Innovation Programme (GA n. 725883 EarlyModernCosmology)

\section{Sources}

\section{Primary}

Agrippa ab Nettesheym, Henricus Cornelius. 1584. De incertitudine et vanitate scientiarum declamatio invectiva, ex postrema authoris recognitione. Coloniae: apud Theodorum Baumium.

Argenterio, Giovanni. 1566. In Artem Medicinalem Galeni, Commentarii tres. In Monte Regali: Ex Officina Torrentiniana.

Cardano, Girolamo. 1663. Hyeronimi Cardani... Opera omnia. Lugduni: Sumptibus Ioannis Antonii Huguetan et Marci Antonii Ravaud.

Cardano, Girolamo. 1962. The Book of My Life: De Vita Propria Liber. Trans. Jean Stoner. New York: Dover Publications.

Castelvetro, Lodovico. 1978. Poetica d'Aristotele vulgarizzata e sposta: Volume One. Bari: Editori Laterza.

Cusanus, Nicolaus. 1932. De docta ignorantia. In Opera Omnia: Volume One, ed. Ernst Hoffmann and Raymond Klibansky, ???. Hamburg: Felix Meiner.

Cusanus, Nicolaus. 1988. On Learned Ignorance. In Complete philosophical and theological treatises of Nicholas of Cusa, transl. by Jasper Hopkins. Minneapolis: Banning Press.

Della Porta, Giambattista. 1650. Magiae naturalis libri viginti. Lugdunum Bataborum: Ex Officina Petri Lessen.

Del Monte, Guidobaldo. 1581. Le mechaniche... tradotte in volgare dal Sig. Filippo Pigafetta. In Venetia: Appresso Francesco di Franceschi Sanese.

Galilei, Galileo. 1914. Dialogues Concerning Two New Sciences. Trans. Henry Crew and Alfonso De Salvio. New York: MacMillan.

Galilei, Galileo. 1960. On Motion and On Mechanics. Trans. Israel E. Drabkin and Stillman Drake. Madison: The University of Wisconsion Press.

Galilei, Galileo. 1968. Le Opere: Nuova ristampa dell'Edizione Nazionale. Florence: Barbèra. Lorini, Bonaiuto. 1596. Delle fortificazioni. In Venetia: Appresso Gio. Antonio Rampazetto. Melanchthon, Philipp. 1550. Initia doctrinae physicae. Witebergae: Lufft.

Patrizi, Francesco. 1969-1971. Della poetica: Three Volumes. Ed. Danilo Aguzzi Barbagli. Florence: Istituto Nazionale di Studi sul Rinascimento. 
Ptolemy. 1553. De praedicationibus astronomicis, cui titulum fecerunt Quadripartitum..., libri III Philippo Melanchthone interprete. Basileae: Oporinus.

Ramelli, Agostino. 1588. Le diverse et artificiose machine. Parigi: in casa del'autore.

Scaliger, Iulius Caesar. 1994. Poetices libri septem: Sieben Bücher über die Dichtkunst, Vol. 1. Ed. Luc Deitz and Gregor Vogt-Spira. Stuttgart-Bad Cannstatt: FrommannHolzboog.

Scotus, John Duns. 1994. Contingency and Freedom: Lectura I 39. Ed. Anthonie Vos Jaczn et al. Dordrecht: Kluwer.

Tartaglia, Niccolò. 1558. La nova scientia. Vinegia: per Curtio Troiano.

Thomas Aquinas 1982: Thomas von Aquin, Summe gegen die Heiden, vol. 2. Darmstadt: Wissenschaftliche Buchgesellschaft, Engl. transl., Summa contra gentiles, Notre Dame: University of Notre Dame Press.

Varchi, Benedetto. 1827. Questione sull'alchimia: Codice inedito. Florence: Stamperia Magheri.

\section{Secondary}

Cassirer, Ernst. 1927. Individuum und Kosmos in der Philosophie der Renaissance. Leipzig: B. G. Teubner.

Gal, Ofer and Raz Chen-Morris. 2013. Baroque Science. Chicago: The University of Chicago Press.

Goldstein, Bernard R. and Giora Hon. 2005. Kepler's Move from Orbs to Orbits: Documenting a Revolutionary Scientific Concept. Perspectives on Science 13/1: 74 111.

Hathaway, Baxter. 1962. The Age of Criticism: The Late Renaissance in Italy. Ithaca: Cornell University Press.

Weinberg, Bernard. 1961. A History of Literary Criticism in the Italian Renaissance. Chicago: The University of Chicago Press.

Kappl, Brigitte. 2006. Die Poetik des Aristoteles in der Dichtungstheorie des Cinquecento. Berlin: Walter de Gruyter.

Koyré, Alexandre. 1957. From the Closed World to the Infinite Universe. Baltimore: The Johns Hopkins University Press.

Kusukawa, Sachiko. 1995. The Transformation of Natural Philosophy: The Case of Philip Melanchthon. Cambridge: Cambridge University Press.

Lefèvre, Wolfgang. 1978. Naturtheorie und Produktionsweise, Probleme einer materialistischen Wissenschaftsgeschichtsschreibung: Eine Studie zur Genese der neuzeitlichen Naturwissenschaft. Darmstadt-Neuwied: Hermann Luchterhand.

Lefèvre, Wolfgang. 2001. Galileo Engineer: Art and Modern Science. In Galileo in Context, ed. Jürgen Renn, 11-27. Cambridge: Cambridge University Press.

Long, Pamela O. 2001. Artisan/Practitioners and the Rise of the New Science, 1400-1600. Corvallis: Oregon State University Press.

Luhmann, Niklas. 2013. Kontingenz und Recht: Rechtstheorie im interdisziplinären Zusammenhang. Berlin: Suhrkamp. 
Mammola, Simone. 2012. La ragione e l'incertezza: Filosofia e medicina nella prima età moderna. Milano: Franco Angeli.

Markschies, Christoph. 2016. "Providence leaves no real room to fortuna:" Vom Zufall bei Augustinus. In Contingentia: Transformationen des Zufalls, ed. Hartmut Böhme, Werner Röcke and Ulrike C. A. Stephan, 39-50. Berlin: Walter de Gruyter.

Omodeo, Pietro Daniel and Jürgen Renn. 2015. Das Prinzip Kontingenz in der Naturwissenschaft der Renaissance. In Contingentia: Transformationen des Zufalls, ed. Hartmut Böhme, Werner Röcke and Ulrike C. A. Stephan, 115-148. Berlin: Walter de Gruyter.

Rossi, Paolo. 1977. La negazione delle sfere e l'astrobiologia di Francesco Patrizi. In Il Rinascimento nelle corti padane: Società e cultura, ed. Paolo Rossi, 401-439. Bari: De Donato.

Rossi, Paolo. 2001. The Birth of Modern Science. Oxford: Blackwell.

Seidengart, Jean. 2006. Dieu, l'univers et la sphère infinie: Penser l'infinité cosmique à l'aube de la science classique. Paris: Éditions Albin Michel.

Schuster, John. 2013. Descartes-Agonistes: Physico-mathematics, Method \& CorpuscularMechanism 1618-33. Dordrecht: Springer.

Schepers, Heinrich. 1965. Zum Problem der Kontingenz bei Leibniz: Die beste der möglichen Welten. In Collegium Philosophicum: Studien Joachim Ritter zum 60. Geburtstag, ed. Ernst-Wolfgang Böckenförde, 326-350. Basle-Stuttgart: Schwabe.

Schmitt, Arbogast. 2002. La Poetica di Aristotele e la sua reinterpretazione nella teoria poetica del Secondo Cinquecento. In La poetica di Aristotele e la sua storia: Atti della giornata internazionale di studio organizzata dal seminario di greco in memoria die Viviana Cessi (Pavia, 22 febbraio 2002), ed. Diego Lanza, 31-44. Pisa: Edizioni ETS.

Smith, Pamela. 2004. The Body of the Artisan: Art and Experience in the Scientific Revolution. Chicago: The University of Chicago Press.

Renn, Jürgen, Peter Damerow and Simone Rieger. 2001. Hunting the White Elephant: When and How did Galileo Discover the Law of Fall? In Galileo in Context, ed. Jürgen Renn, 29-149. Cambridge: Cambridge University Press.

Secchi, Pietro. 2006. "Del mar più che del ciel amante:" Bruno e Cusano. Rome: Edizioni di Storia e Letteratura.

Temkin, Owsei. 1973. Galenism: Rise and Decline of a Medical Philosophy. Ithaca: Cornell University Press.

Valleriani, Matteo. 2010. Galileo Engineer. Dordrecht: Springer.

Valleriani, Matteo. 2013. Metallurgy, Ballistics and Epistemic Instruments: The Nova scientia of Nicolò Tartaglia. Berlin: Edition Open Access.

Valleriani, Matteo. 2017. Practical Knowledge. Boston: Springer.

Vogt, Peter. 2011. Kontingenz und Zufall: Eine Ideen- und Begriffsgeschichte. Berlin: Akademie.

Wilson, Curtis A. 1968. Kepler's Derivation of the Elliptical Path. Isis 59/1: 4-25. 